\title{
Simulation study for the formation of alkaline efflorescence on bauxite residue disposal areas following the phosphogypsum addition
}

by Wu, Y., Li, M., Fu, D., Santini, T.C., Jiang, J., Hartley, W. and Xue, $S$.

Copyright, publisher and additional Information: This is the author accepted manuscript. The final published version (version of record) is available online via Elsevier.

This version is made available under the CC-BY-ND-NC licence:

https://creativecommons.org/licenses/by-nc-nd/4.0/legalcode

Please refer to any applicable terms of use of the publisher

DOI: https://doi.org/10.1016/j.jclepro.2020.121266 

residue disposal areas following the phosphogypsum addition

\author{
Yujun $\mathrm{Wu}^{\mathrm{a}}$, Meng $\mathrm{Li}^{\mathrm{a}}$, Ding $\mathrm{Fu}^{\mathrm{b}}$, Talitha C. Santini ${ }^{\mathrm{c}}$, Jun Jiang ${ }^{\mathrm{a}}$, Hartley William ${ }^{\mathrm{d}}$, \\ ShengguoXue $\mathrm{e}^{\mathrm{a}, *}$ \\ a. School of Metallurgy and Environment, Central South University, 932 Lushan South Road, \\ Changsha, 410083, PR China \\ b. Business School, Beijing Normal University, 19 Xinjiekouwai Street, Beijing, 100875, P.R. \\ China \\ c. School of Agriculture and Environment, The University of Western Australia, 35 Stirling \\ Highway, Crawley, Western Australia 6009, Australia \\ d. Crop and Environment Sciences Department, Harper Adams University, Newport, \\ Shropshire, TF10 8NB, United Kingdom
}

\title{
Abstract
}

Bauxite residue is a solid, highly alkaline byproduct (tailings) generated in the alumina refining process. The process that forms the fine white salt deposits on the surface of bauxite residue following prolonged dry periods, and which also forms on products made from reused residues (sintered bricks, etc.), is known as efflorescence. It not only seriously affects the utilization of bauxite residue in building materials, but also creates potential dust pollution around the BRDAs, which means it would require sustained and intensive resources to manage and transform its alkalinity. Through a laboratory simulation experiment using soil leaching columns, we show that the extent of bauxite residue efflorescence is affected by many factors, including porosity, initial water content, bauxite residue particle size. The main soluble mineral precipitates of efflorescence are $\mathrm{Na}_{2} \mathrm{CO}_{3}$ and $\mathrm{NaHCO}_{3}$. Addition of phosphogypsum, a common amendment to reduce dispersion and promote removal of $\mathrm{Na}^{+}$through leaching, shifted the composition of effloresced salts to favor $\mathrm{Na}_{2} \mathrm{SO}_{4} \cdot 10 \mathrm{H}_{2} \mathrm{O}$. SEM and $\mathrm{Na}$ K-edge X-ray absorption near-edge structure (XANES)spectroscopy demonstrated that free alkali migrates to the residue surface to precipitate as a uniform agglomerate in the efflorescence process, which also changes the chemical form of $\mathrm{Na}$-containing minerals in the bauxite residue and the mesoscale spatial distribution of $\mathrm{Na}$ (soft $\mathrm{X}$-ray scanning transmission microscopy imaging). Free alkali migration with water is the main driver of efflorescence, and this work also demonstrated that phosphogypsum can reduce the 
generation of alkaline efflorescence for ameliorating alkaline dust pollution from bauxite residue.

\section{Keywords}

Bauxite residues, efflorescence, phosphogypsum, alkaline substance, alkalinity migration 1. Introduction

Bauxite residue is the solid byproduct (tailings) generated after extracting alumina from bauxite via the Bayer process, sintering process, and combined Bayer-sintering process. The current global stock of bauxite residue is estimated at 4.6 billion tons, and the annual increase in bauxite residue in China alone is estimated at 200 million tons, mainly deposited by dry stacking (solids content 50-65 wt.\%) (Xue et al., 2019a). Bauxite residue has a high alkali content, which creates serious challenges for storage and utilization (Wen et al., 2016; Xue et al., 2016; Yoon et al., 2019). The substantial amount of bauxite residue in bauxite residue disposal areas (BRDAs) not only occupies large areas of otherwise productive land (Sofra and Boger, 2002; Liu et al., 2009; Xue et al., 2020), but can also be a source of fugitivedust emissions which result in environmental and air pollution. These dust emissions are exacerbated by high winds and/or low rainfall (Klauber et al., 2013; Kong et al., 2017a; Xu et al., 2018). Bauxite residue has a fine particle size, concentrated in the range of 2 to 100 $\mu \mathrm{m}$ (Grafe et al., 2011; Zhu et al., 2017), and these fine bauxite residue particles (including minerals such as hematite $\left(\mathrm{Fe}_{2} \mathrm{O}_{3}\right)$, calcite $\left(\mathrm{CaCO}_{3}\right)$, and desilication product minerals such as hydrogarnet $\left(\left(\mathrm{Ca}_{3} \mathrm{Al}_{2}(\mathrm{SiO} 4)_{\mathrm{x}}(\mathrm{OH})_{12-4 \mathrm{x}}\right)\right.$ and cancrinite $\left(\mathrm{Na}_{8} \mathrm{Al}_{6} \mathrm{Si}_{6} \mathrm{O}_{24}\left(\mathrm{CO}_{3}\right)\left(\mathrm{H}_{2} \mathrm{O}\right)_{2}\right)$ contribute to dust emissions from BRDAs (Gelencser et al., 2011). Much of the fugitive dust emissions also comprise salts precipitated at the residue surface through efflorescence. These salts typically appear as a layer of white material on the bauxite residue surface after deposition in BRDAs, through capillary rise of dissolved alkali in pore water and evaporation of water at the residue surface (Klauber et al., 2013). Sodium ions can't form stable hydration layers and can't be coordinated with negatively charged surfaces, which results in the particles of fresh bauxite residue disaggregating and hence a crusted surface forms as $\mathrm{Na}$ eventually 
precipitates out as soda ash (trona and nahcolite) (Kong et al., 2017a). The soluble alkaline substances in bauxite residue diffuse to its surface, and react with $\mathrm{CO}_{2}$ in the atmosphere, to form white monohydrate carbonate deposits on the surface. Higgins et al. (2018) found that carbonation of bauxite residue leachate is an important component of passive treatments and neutralization. The rate of in-gassing and diffusion of $\mathrm{CO}_{2}$ controls the depth to which this process can act within bauxite residue. Bray et al. (2018) demonstrated that atmospheric $\mathrm{CO}_{2}$ in-gassing appears to extend $\sim 20 \mathrm{~cm}$ below the surface. Hence, efflorescence is partially controlled by the balance between $\mathrm{CO}_{2}$ infiltration from the atmosphere. The effloresced minerals include strongly alkaline (often sodium-based) salts such as sodium carbonate (soda ash; $\left.\mathrm{Na}_{2} \mathrm{CO}_{3}\right)$, trona $\left(\mathrm{Na}_{2} \mathrm{CO}_{3} \cdot \mathrm{NaHCO}_{3} \cdot 2 \mathrm{H}_{2} \mathrm{O}\right)$, and nahcolite $\left(\mathrm{NaHCO}_{3}\right)($ Klauber et al., 2013), which can cause impacts to the surrounding environment and human health. Efflorescence also negatively affects the utilization prospects for bauxite residue in construction applications. Delamination and crumbling due to efflorescence of alkali salts impacts visual appearance of building materials using bauxite residue as well as decreasing the longevity and strength of the material (Wang et al., 2018; Huang et al., 2014).

In warmer climates, unregulated bauxite residue disposal areas can be a significant source of fugitive dust emissions, which result in the health hazard posed by the inhalation of caustic compounds. At present, dust control in bauxite residue deposits is primarily achieved by chemical stabilizers or irrigation (water application). Chemical stabilizers are difficult to apply, high cost, temporary in effect, and pose additional issues for energy consumption and environmental management (e.g. downstream impacts to groundwater and the tailings themselves) (Indraratna et al., 2013; Rollings et al., 1999; Vinod et al., 2010; Gomes et al., 2016). Polymer stabilizers are an emerging approach technology but have only been tested on residue sand (coarse fraction) (Ding et al., 2019) and are not yet employed at field scale. At present, the most common efflorescence suppression approaches for bauxite residue are $\mathrm{pH}$ neutralization (dealkalization; mostly for residues in BRDAs) or sodium stabilization 
91 (mostly for residues reused in building applications). $\mathrm{pH}$ neutralization, destroying free alkali, can be achieved by water washing, application of inorganic or organic acids, and other methods such as seawater application (Luo et al., 2017; Johnston et al., 2010; Khaitan et al., 2009; Lehoux et al., 2013; Santini and Peng, 2017; Santini et al., 2015; Smiciklas et al., 2014; Collins et al., 2014). Sodium stabilization refers to the incorporation of previously free sodium into sparingly soluble or insoluble minerals, usually through high temperature treatment such as sintering (Mishra et al., 2002; Hong and Glasser, 2002; Wieslawa, 1999).

There is currently a gap in knowledge linking the nature and formation mechanism of fugitive dusts from efflorescence in a BRDA to the development and implementation of a tailored dust/efflorescence suppression approach that targets the root cause(s) of efflorescence in bauxite residue. Understanding the chemistry behind the efflorescence process gives the best opportunity to target appropriate lower cost mitigation strategies, rather than implementing a suite of traditional binders and stabilizers developed for other dust sources. Application of phosphogypsum (a residue produced during $\mathrm{P}$ fertilizer production) may offer one such opportunity to target the root cause(s) of efflorescence by simultaneously decreasing free alkali and the high sodicity of bauxite residue(Shi et al., 2017; Jones et al., 2011; Sharma et al., 2004; Li et al., 2019). Most of the focus to date relating to (phospho-) gypsum application in residue has been focused on amelioration of residue properties to promote vegetation establishment and growth (Bray et al., 2018; Courtney and Timpson, 2004; Courtney and Harrington, 2012; Courtney et al., 2014; Courtney and Xue, 2019). Although the effects of gypsum in decreasing $\mathrm{pH}$ and replacing free and exchangeable $\mathrm{Na}^{+}$with $\mathrm{Ca}^{2+}$ have been consistently noted in these studies, no study to date has specifically investigated the role of phosphogypsum in producing efflorescence and reducing alkaline dust generation from bauxite residues.

This study is therefore focused on understanding the key solutes and transport processes underpinning efflorescence in bauxite residue, with and without 
121 phosphogypsum application, as a commonly in-situ remediation amendment for 122 application in BRDAs. Through a laboratory soil column experiment, we investigated:

123 1) the chemical and mineral composition of effloresced salts at bauxite residue surfaces; 2) the process and key factors controlling the composition and quantity of effloresced salts; 3) the role of phosphogypsum application in reducing the composition and quantity of alkaline effloresced salts. Based on results from this study, we provide recommendations for the management of efflorescence in BRDAs and the large-scale utilization of bauxite residue resources in building and construction materials in the future.

\section{Material and methods}

\subsection{Samples}

The bauxite residue used in the experiment was taken from a BRDA in Guangxi, China $\left(23^{\circ} 18^{\prime} \mathrm{N}, 107^{\circ} 31^{\prime} \mathrm{E}\right)$. Samples were fresh bauxite residues (deposited less than one month and untreated), randomly sampled in the BRDA, evenly mixed to create one homogeneous sample, and then dried at room temperature to constant weight. Gravel (fragments $>2 \mathrm{~mm}$ in diameter) was removed by hand and the residue was sieved to $<0.84 \mathrm{~mm}$ (20 mesh). The initial geochemical and physical properties of the bauxite residue used in the experiment are shown in Table 1.

\subsection{Experimental design and apparatus}

A simulation experiment using a laboratory soil column was conducted to study the process of efflorescence. The effect of experimental scale on the simulation results, and the difference between laboratory conditions and field conditions, was also considered. The column comprised a polymethyl methacrylate (PMMA) cylinder (height $95 \mathrm{~cm}$; inner diameter $12.6 \mathrm{~cm}$ ), into which six sampling holes (diameter $2 \mathrm{~cm}$ ) spaced $10 \mathrm{~cm}$ apart from each other along the longitudinal axis were drilled (Fig.1). The water collector was positioned underneath the column, and the water dripper (attached to a peristaltic pump) was positioned above the column. 
Two soil columns were established for the experiment, each containing a layer of 152 gauze (nylon, $0.45 \mathrm{~mm}$ ) placed on the porous baffle (stainless steel) at the bottom of the soil column, then a $15 \mathrm{~cm}$ layer of quartz sand. Column 1 (C1) was then filled with $80 \mathrm{~cm}$ of bauxite residue to simulate unamended BRDAs; whereas column 2 (C2) was filled with $55 \mathrm{~cm}$ of bauxite residue at the bottom and then $25 \mathrm{~cm}$ of bauxite residue at the top amended with $2 \%$ (wt.\%) phosphogypsum to simulate phosphogypsum-amended BRDAs. After filling the two columns, the peristaltic pump was used to saturate the residue with distilled water. Columns were then equilibrated for 48 hours prior to the commencement of leaching. Columns were leached with distilled water every two days in the first 60 days, at a pro-rata volume equivalent to that of the average annual rainfall in Guangxi $(1800 \mathrm{~mm})$, after which leaching was terminated and the columns were monitored for a further 270 days. Efflorescence appeared on the 90th day, and was sustained to the 150th day. After 150 days, efflorescence was difficult to observe. Hence, effloresced salts were sampled on the 150th day from columns $\mathrm{C} 1$ and $\mathrm{C} 2$. Fig. 2 shows the daily air temperature and humidity averages in the laboratory from 0 to 100 days.

\subsection{Analytical and statistical methods}

During the leaching procedure, residues were collected at $0,5,15,25,35,45$, and 55 cm's depth on the 30th, 60th, 90th, 150th, 210th, 270th and 330th day with a spatula through each sampling hole (the $0 \mathrm{~cm}$ depth refers to the surface layer of the columns which sampled in the upper $0-1 \mathrm{~cm}$ ). Three replicates were collected from different sampling holes which were positioned around the column at each sampling depth. Effloresced salts were removed by scraping them from the surface of the columns. The effloresced salt sample contained a small amount of bauxite residues from the surface layer $(0-1 \mathrm{~cm}$ depth) due to the small volume of material produced and the fact that the surface becomes cemented once the material is deposited. All samples were air-dried and then sieved to $0.84 \mathrm{~mm}$ (20 mesh) prior to analysis. The $\mathrm{pH}$ was 
measured with an acidity meter (PHS-3C), and the solid-to-liquid ratio was $\mathrm{m}$ (solid): $\mathrm{v}$ (liquid) $=1: 5$ (Kong et al., 2017a). Subsequent to $\mathrm{pH}$ determination, the supernatant liquors were mixed at $150 \mathrm{rpm}(1 \mathrm{~h})$ then centrifuged at $3000 \mathrm{rpm}(10 \mathrm{~min})$ and analyzed for $\mathrm{CO}_{3}{ }^{2-}$ and $\mathrm{HCO}_{3}{ }^{-}$concentrations, which were determined by double indicator-neutralization titration using $\mathrm{H}_{2} \mathrm{SO}_{4}(0.005 \mathrm{~mol} / \mathrm{L})$ (Kong et al., 2017b).Aluminum concentrations and soluble concentrations of $\mathrm{Na}$ and $\mathrm{Ca}$ in all prepared supernatants were determined by ICP-AES (Optima 5300DV inductively coupled plasma spectrometer, Perkin Elmer) (Huang et al., 2016). Bauxite residue/effloresced $\mathrm{Al}(\mathrm{OH})_{4}^{-}$content was calculated by the $\mathrm{Al}$ concentrations in supernatants. Air temperature and humidity were determined using a wet and dry thermometer (HTC-1). Bulk density was determined on naturally compacted samples using the cutting ring method, and moisture content was determined using the weight method. Capillary porosity was calculated by multiplying the two together (Jones et al., 2011). Particle morphologies and sizes were measured using SEM (FET Quanta-200) and a laser scattering particle size analyzer (Malvern Mastersizer 2000 MS, UK). XRD for mineral identification was conducted on a Bruker D8 Discover 2500 with a $\mathrm{Cu} \mathrm{K} \mathrm{K}_{\mathrm{a} 1}$ anode, using a Sol-X detector (LynxEye array). Near edge X-ray absorption spectroscopy (NEXAFS) experiments were performed on the BL08U1A beamline of the Shanghai Synchrotron Radiation Facility (SSRF, Shanghai, China). Distribution of $\mathrm{Na}$ in the residual solids was analyzed by soft X-ray scanning transmission microscopy (STXM); the specific determination method is detailed in Kong et al. (2017b).

SPSS Statistics 24 software was used to analyze significant differences. The results of test data are mean \pm standard deviation. Significant differences of the relative parameters were statistically analyzed using significance F test and Duncan multiple comparison method $(p<0.05$ and $p<0.01)$. All figures were produced using Origin V8.5 software. 


\subsection{Efflorescence analysis}

Efflorescence material on the surface of bauxite residue is closely related to the high alkaline species contained in the residue. The alkaline materials are commonly divided into two categories: free alkali and chemically bound alkali. Chemically bound alkali is produced in the process of pre-desilication, leaching and separation via a series of mineralization and chemical reactions. Due to its low solubility, good buffering performance and complex structure, it mainly exists in the form of mineral phases, including calcite $\left(\mathrm{CaCO}_{3}\right)$, cancrinite $\left(\mathrm{Na}_{8} \mathrm{Al}_{6} \mathrm{Si}_{6}\left(\mathrm{CO}_{3}\right) \mathrm{O}_{24} \cdot 2 \mathrm{H}_{2} \mathrm{O}\right)$, hydrogarnet $\left(\mathrm{Ca}_{3} \mathrm{Al}_{2}\left(\mathrm{SiO}_{4}\right)_{x}(\mathrm{OH})_{12-4 x}\right)$, sodalite $\left(\mathrm{Na}_{8} \mathrm{Al}_{6} \mathrm{Si}_{6} \mathrm{O}_{24} \mathrm{Cl}_{2}\right)$, and tricalcium aluminate (TCA, $\mathrm{Ca}_{3} \mathrm{Al}_{2}(\mathrm{OH})_{12}$ ). As revealed in dissolution equations 1 to 5 , these mineral phases are capable of dissolving and generating $\mathrm{OH}^{-}$and $\mathrm{CO}_{3}{ }^{2-}$ under certain conditions (Xue et al., 2019b; Kong et al., 2017a). The other typical alkaline substances are free alkali, which mainly includes $\mathrm{NaOH}, \mathrm{Na}_{2} \mathrm{CO}_{3}, \mathrm{NaHCO}_{3}$, $\mathrm{NaAl}(\mathrm{OH})_{4}, \mathrm{~K}_{2} \mathrm{CO}_{3}$ and $\mathrm{KOH}$. The free alkali anions originate from dissolution of free alkali which form a strong buffer system to maintain the $\mathrm{pH}$ between 9.2 to 12.3.

$\mathrm{CaCO}_{3} \rightarrow \mathrm{Ca}^{2+}+\mathrm{CO}_{3}{ }^{2-}$

$\mathrm{Na}_{8} \mathrm{Al}_{6} \mathrm{Si}_{6} \mathrm{O}_{24}\left(\mathrm{CO}_{3}\right)\left(\mathrm{H}_{2} \mathrm{O}\right)_{2}+22 \mathrm{H}_{2} \mathrm{O} \rightarrow 8 \mathrm{Na}^{+}+6 \mathrm{Al}(\mathrm{OH})_{3}+6 \mathrm{H}_{4} \mathrm{SiO}_{4}+6 \mathrm{OH}^{-}+\mathrm{CO}_{3}{ }^{2-}$

$\mathrm{Ca}_{3} \mathrm{Al}_{2}\left(\mathrm{SiO}_{4}\right)_{x}(\mathrm{OH})_{12-4 x} \rightarrow 3 \mathrm{Ca}^{2+}+2 \mathrm{Al}(\mathrm{OH})_{3}+x \mathrm{H}_{4} \mathrm{SiO}_{4}+(6-4 \mathrm{x}) \mathrm{OH}^{-}$

$\mathrm{Na}_{8} \mathrm{Al}_{6} \mathrm{Si}_{6} \mathrm{O}_{24} \mathrm{Cl}_{2}+24 \mathrm{H}_{2} \mathrm{O} \rightarrow 8 \mathrm{Na}^{+}+6 \mathrm{Al}(\mathrm{OH})_{3}+6 \mathrm{H}_{4} \mathrm{SiO}_{4}+6 \mathrm{OH}^{-}+2 \mathrm{Cl}^{-}$

$\mathrm{Ca}_{3} \mathrm{Al}_{2}(\mathrm{OH})_{12} \rightarrow 3 \mathrm{Ca}^{2+}+2 \mathrm{Al}(\mathrm{OH})_{3}+6 \mathrm{OH}^{-}$

Effloresced material harvested from column $\mathrm{C} 1$ was less than that from column $\mathrm{C} 2$. Therefore, material from C1 was only used for SEM, XRD and XANES analyses (see later sections). The change in typical alkaline anion content of soluble effloresced material in $\mathrm{C} 2$ is shown in Table 2 (it should be noted that time 0 day here refers to the upper $0-1 \mathrm{~cm}$ of pure bauxite residue). The $\mathrm{pH}$ of effloresced substances increased by nearly one unit, from 10.42 to 11.02 . Two typical alkaline anions, $\mathrm{CO}_{3}{ }^{2-}$ and $\mathrm{HCO}_{3}{ }^{-}$, present in soluble alkaline substances, increased their contents significantly from 141.3 and $31.28 \mathrm{mmol} / \mathrm{L}$ to 256.7 and $46.84 \mathrm{mmol} / \mathrm{L}$ respectively, indicating that they are still the main components of effloresced substances. Efflorescence continued to 
occur in column $\mathrm{C} 2$ during the latter 90 to 150 days. The main period of efflorescence is typically 90-120 days, and alkaline anion content changes significantly, but with little change during the last 30 days. Total mass of effloresced salts in $\mathrm{C} 2$ column is relatively large, indicating that phosphogypsum influenced salt production. With time, water in $\mathrm{C} 2$ evaporated, halting the efflorescence process.

Fig. 3 shows the change in soluble cations $\left(\mathrm{Na}^{+}\right.$and $\left.\mathrm{Ca}^{2+}\right)$ in $\mathrm{C} 2$, which increased during the process of efflorescence.The main period of efflorescence occurred during the first 30 days, were $\mathrm{Na}^{+}$and $\mathrm{Ca}^{2+}$ concentrations changed greatly. In comparison to the original bauxite residue, $\mathrm{Na}^{+}$and $\mathrm{Ca}^{2+}$ ions increased from 76.34 and $3.12 \mathrm{mmol} / \mathrm{L}$ to 216.9 and $8.36 \mathrm{mmol} / \mathrm{L}$ respectively, indicating that sodium salt is the main soluble substance responsible for efflorescence production. That is, $\mathrm{Na}_{2} \mathrm{CO}_{3}$ and $\mathrm{NaHCO}_{3}$ are the main soluble components in effloresced substances, this is consistent with the results of Klauber et al. (2013), which revealed efflorescence formation along with a changing phase composition in brine solids from sodium bicarbonate through to trona and then to carbonate monohydrate. In addition to the soluble effloresced salts, insoluble effloresced salts of $\mathrm{CaCO}_{3}$ were found in $\mathrm{C} 2$ column, with the net reaction for this mechanism present in Eqs.6 (Burke et al., 2013; Lehoux et al., 2013).

$$
\mathrm{CaSO}_{4} \cdot 2 \mathrm{H}_{2} \mathrm{O}+2 \mathrm{OH}+\mathrm{CO}_{2} \rightleftharpoons \mathrm{CaCO}_{3}+\mathrm{SO}_{4}{ }^{2-}+3 \mathrm{H}_{2} \mathrm{O}
$$

\section{$3.2 \mathrm{pH}$ and alkaline anion migration}

$\mathrm{pH}$ in unamended bauxite residue $(\mathrm{C} 1)$ decreased during the experiment, with $\mathrm{pH}$ values ranging from $\mathrm{pH}$ 9.76-11.02 (Fig. 4). Some variation in residue $\mathrm{pH}$ was observed with depth. Surface $\mathrm{pH}(0-1 \mathrm{~cm}$ depth) decreased from 0-60 days, then increased from 90-150 days, then decreased again from 120-330 days (Fig. 4). The increase in surface $\mathrm{pH}$ at 90-150 days coincides with efflorescence at this time, as discussed in Section 3.1, and likely reflects the dominance of alkali salts in the efflorescence. The largest decrease in residue $\mathrm{pH}$ occurred between 0-30 days, reflecting export of soluble alkaline substances in the bauxite residue to lower layers 
of the soil column with the continuous migration of water, and eventual exit from the leaching column.

In the phosphogypsum-amended residue column (C2), residue $\mathrm{pH}$ was substantially lower in the upper 0-30 $\mathrm{cm}$ at time $0(\mathrm{pH} 8.5-9.5)$ than in the unamended residue column (C1; pH 10.7-11.0) (Fig. 4). The $\mathrm{pH}$ of phosphogypsum is low (approximately 2.5), and the addition of $\mathrm{Ca}^{2+}$ in phosphogypsum aids in $\mathrm{pH}$ neutralization through removal of $\mathrm{OH}^{-}$and $\mathrm{CO}_{3}{ }^{2-}$ from solution as $\mathrm{Ca}(\mathrm{OH})_{2}$ and $\mathrm{CaCO}_{3}$ (Eqs.7, 8) (Li et al., 2018; Courtney and Timpson, 2004; Menzies et al., 2004; Suryavanshi et al., 1996; Paradis et al., 2007). As well as neutralizing residue $\mathrm{pH}$, these reactions contributed to reducing efflorescence of sodium-based alkali salts at the surface during the drying phase of the experiment. Although some increases in surface $(0-1 \mathrm{~cm}) \mathrm{pH}$ of residue were observed in the $\mathrm{C} 2$ column at $90-150$ days ( $\mathrm{pH}$ at 60 days: 8.6; $\mathrm{pH}$ at 90 days: 9.21; $\mathrm{pH}$ at 150 days: 9.92), these were much lower than those observed in $\mathrm{C} 1$ ( $\mathrm{pH}$ at 60 days: 10.1; $\mathrm{pH}$ at 90 days: 10.71; $\mathrm{pH}$ at 150 days: 11.02; Fig. 4). The results of $\mathrm{pH}$ changes with depth are similar to Bray et al. (2018).

$\mathrm{Ca}^{2+}+2 \mathrm{OH}^{-}=\mathrm{Ca}(\mathrm{OH})_{2}$

$\mathrm{Ca}^{2+}+\mathrm{CO}_{3}{ }^{2-}=\mathrm{CaCO}_{3}$

Free alkali is an important contributor to bauxite residue alkalinity, including salts such as $\mathrm{NaOH}, \mathrm{Na}_{2} \mathrm{CO}_{3}, \mathrm{NaHCO}_{3}, \mathrm{NaAl}(\mathrm{OH})_{4}, \mathrm{~K}_{2} \mathrm{CO}_{3}$ and $\mathrm{KOH}$. These salts are readily dissolved to generate the alkaline anions $\mathrm{OH}^{-}, \mathrm{CO}_{3}{ }^{2-}, \mathrm{HCO}_{3}{ }^{-}$, and $\mathrm{Al}(\mathrm{OH})_{4}^{-}$. We focused on concentrations of $\mathrm{CO}_{3}{ }^{2-}$ and $\mathrm{HCO}_{3}{ }^{-}$in the bauxite residue as these dominate solution chemistry at the prevailing $\mathrm{pH}$ observed in the columns ( $\mathrm{Li}$ et al., 2018). Trends in summed concentrations of $\mathrm{CO}_{3}{ }^{2-}$ and $\mathrm{HCO}_{3}{ }^{-}$(termed as alkaline anion concentrations) in column $\mathrm{C} 1$ mirrored those of $\mathrm{pH}$ with depth and with time, decreasing overall during the experiment and with a substantial increase in surface concentrations coincident with efflorescence at 90-150 days (Fig. 4). This is consistent with water movement being the major control on migration of alkaline anions within unamended residue. Unlike $\mathrm{C} 1$, trends in summed concentrations of $\mathrm{CO}_{3}{ }^{2-}$ and $\mathrm{HCO}_{3}{ }^{-}$in the phosphogypsum amended column $\mathrm{C} 2$ differed to those of $\mathrm{pH}$. 
Application of phosphogypsum in the upper $25 \mathrm{~cm}$ of residue substantially decreased alkaline anion concentrations at time zero, with alkaline anion concentrations in the 0-30 $\mathrm{cm}$ depths of $<20 \mathrm{mmol} / \mathrm{L}$ in $\mathrm{C} 2$ compared to $235-270 \mathrm{mmol} / \mathrm{L}$ in $\mathrm{C} 1$ (Fig. 4). Alkaline anion concentrations then increased with depth (at time zero) in C2 to reach a maximum of $235 \mathrm{mmol} / \mathrm{L}$ at $55 \mathrm{~cm}$ (Fig. 4), like that of unamended residue in $\mathrm{C} 1$. As leaching proceeded over the first 60 days, alkaline anion concentrations decreased in the 30-60 $\mathrm{cm}$ depths of $\mathrm{C} 2$ which likely reflects both slow dissolution of phosphogypsum and reaction of $\mathrm{Ca}^{2+}$ with $\mathrm{CO}_{3}{ }^{2-}$ and $\mathrm{HCO}_{3}{ }^{-}$in solution, as well as washout (export) of residual dissolved $\mathrm{HCO}_{3}{ }^{-}$and $\mathrm{CO}_{3}{ }^{2-}$ from the leaching column (Fig. 4). At time 90 days and during the remainder of the experiment, alkaline anion concentrations were substantially lower in $\mathrm{C} 2$ (all $<80 \mathrm{mmol} / \mathrm{L}$ at all depths) than in C1 (205-305 mmol/L at all depths) (Fig. 4). As observed in C1, alkaline anion concentrations increased at the surface of $\mathrm{C} 2$ during the initial phase of drying (90-150 days), consistent with efflorescence of alkali salts.

After collecting the effloresced substances on the bauxite residue surface on the 150th day, $\mathrm{pH}$ and alkaline anion content of bauxite residue at all depths continued to show small decreases between the 210th and 330th days, but this range will become negligible over longer periods. Previous work revealed that repeated replacement of pore water does not alter the final $\mathrm{pH}, \mathrm{Na}^{+}, \mathrm{CO}_{3}{ }^{2-}$, or $\mathrm{OH}^{-}$contents due to the alkalinity released (Thornber and Binet, 1999).

\subsection{Factors influencing efflorescence}

The bauxite residue capillary porosity at different depths in $\mathrm{C} 1$ and $\mathrm{C} 2$ varied with time of 0-150 days (Fig.5a). The capillary porosity at different depths $(0,25,45 \mathrm{~cm})$ in $\mathrm{C} 1$ column was basically unchanged, while the capillary porosity at $0,25,45 \mathrm{~cm}$ in $\mathrm{C} 2$ column gradually increased with the extension of time, and there were significant differences between 30,60, 90, 120 and 150 days and 0 days $(p<0.05)$. It indicates 
that the addition of phosphogypsum can increase the capillary porosity of bauxite residue, which promotes the upward transportation of soluble salts. The moisture content of bauxite residue at different depths in $\mathrm{C} 1$ and $\mathrm{C} 2$ columns gradually decreased with the increases of time (Fig. 5b), especially when the leaching was suspended since the 60th days, the magnitude of reduction reached a maximum, and there were significant differences between the 90-150th days and 0-60th days ( $p<$ 0.01). The water in bauxite residue loss rapidly indicates that bauxite residue has a poor water retention ability, which has an adverse effect on the efflorescence, because the majority of soluble salts are transported to the surface of bauxite residue by water migration, thus causing spontaneous efflorescence formation.

The Fig.5c showed the comparison of the particle size of the bauxite residue (sampled at the end of experiments of day 330) at $25 \mathrm{~cm}$ and $45 \mathrm{~cm}$ depth in column $\mathrm{C} 1$ and $\mathrm{C} 2$. It illustrated that the particle size changed little between the depth of 25 and $45 \mathrm{~cm}$ column $\mathrm{C} 1$, whilst compared to the correspondingly same depth in column $\mathrm{C} 2$, the volume fraction of particle size range in $0.1-1$ um increased from 0.5 to $1.5 \%$, and that of $100-1000 \mathrm{um}$ increased from 1 to $3.3 \%$. It indicates that the particle size of bauxite residue in C2 column increases with the increase of depth, which is related to the application of phosphogypsum. Previous studies have proved that phosphogypsum can promote the formation of large aggregates of bauxite residue (Xue et al., 2019). The increase of particle size of bauxite residue also means that getting more porosities between bauxite residue particles, which is conducive to the migration of water to the surface and promotes the efflorescence forming at the surface of bauxite residue to some extent (Zhu et al., 2016).

\subsection{Mineralogy and morphology of effloresced salts}

The samples of the surface efflorescence substances $(0-1 \mathrm{~cm})$ and the bauxite residue at $45 \mathrm{~cm}$ depth were selected to analyze the mineral phase composition (Fig.6) Hematite $\left(\mathrm{Fe}_{2} \mathrm{O}_{3}\right)$ is a major mineral component of bauxite residue, with calcite 
$\left(\mathrm{CaCO}_{3}\right)$, tricalcium aluminate $\left(\mathrm{Ca}_{3} \mathrm{Al}_{2}(\mathrm{OH})_{12}\right)$, cancrinite $\left(\mathrm{Na}_{8} \mathrm{Al}_{6} \mathrm{Si}_{6} \mathrm{O}_{24}\left(\mathrm{CO}_{3}\right)\left(\mathrm{H}_{2} \mathrm{O}\right)_{2}\right)$ and hydrogarnet $\left(\mathrm{Ca}_{3} \mathrm{Al}_{2}\left(\mathrm{SiO}_{4}\right)_{\mathrm{x}}(\mathrm{OH})_{12-4 \mathrm{x}}\right)$ as the main alkaline mineral phases in both $\mathrm{C} 1$ and $\mathrm{C} 2$ (Fig. 6). The five minerals in the bauxite residue persist in $\mathrm{C} 1$ and $\mathrm{C} 2$ throughout the trials, as observed in the similarity in XRD patterns collected from both columns at $45 \mathrm{~cm}$ depth below surface at day 150. The surface 0-1 cm samples in both $\mathrm{C} 1$ and $\mathrm{C} 2$ were dominated by effloresced salts, chiefly sodium sulfate $\left(\mathrm{Na}_{2} \mathrm{SO}_{4} \cdot 10 \mathrm{H}_{2} \mathrm{O}\right)$. This reflects the dominance of $\mathrm{Na}^{+}$and $\mathrm{SO}_{4}{ }^{2-}$ in bauxite residue pore water wt.\% (Santini et al., 2011; Santini and Fey, 2012), which are brought to the surface by capillary rise. A large peak of sodium sulfate $\left(\mathrm{Na}_{2} \mathrm{SO}_{4} \cdot 10 \mathrm{H}_{2} \mathrm{O}\right)$ appears in the mineral phase of the surface efflorescence sample, the peak strength of calcite also decreased significantly while the peak of hydrogarnet and cancrinite disappeared.

As visible in the sample at $45 \mathrm{~cm}$ in $\mathrm{C} 1$ column (Fig. 7b), the unamended bauxite residue showed morphology dominated by loose, rounded and platy particles varying in size from approximately 50 to $500 \mathrm{~nm}$ in diameter. The morphology of bauxite residue above which phosphogypsum had been applied (Fig. 7d; $45 \mathrm{~cm}$ depth in C2) showed some agglomerations of the smaller particles visible in Fig. $7 b$ into larger aggregates, with an absence of platy particles. This may be due to the effect of added phosphogypsum precipitating out excess $\mathrm{Ca}^{2+}$ as $\mathrm{CaCO}_{3}$ which cemented smaller particles together. The surface efflorescence samples of $\mathrm{C} 1$ and $\mathrm{C} 2$ columns (Fig. 7a/c) showed smooth, platy (and occasionally acicular in C1, and occasionally fibrous in C2) particles of diameters 100-500 $\mathrm{nm}$. Electron microprobe analysis of effloresced salts from $\mathrm{C} 1$ and $\mathrm{C} 2$ confirmed substantially higher concentrations of sodium in these salts (C1: 12.78 wt.\%; C2: 30.92 wt.\%) than in the bulk residue $(\mathrm{C} 1: 3.28$ wt.\%; $\mathrm{C} 2$ : 5.52 wt.\%), consistent with XRD results reported above showing a dominance of $\mathrm{Na}_{2} \mathrm{SO}_{4} \cdot 10 \mathrm{H}_{2} \mathrm{O}$ in the effloresced salts. Surface treatment with phosphogypsum can promote the formation of stable macroaggregates to form new particlesand accelerate the occurrence of efflorescence forming at the surface of bauxite residue. Another study has reported that phosphogypsum changed the microstructure and surrounding pores of residue aggregates (Xue et al., 2020). Therefore, selecting the appropriate 
way to transform the efflorescence substances can not only effectively reduce the alkalinity of bauxite residue, but also promote the soil formation process of bauxite residue.

\subsection{Phase equilibrium diagram of $\mathrm{Na}_{2} \mathrm{CO}_{3}$ and $\mathrm{Na}_{2} \mathrm{SO}_{4}$}

Of particular interest in this efflorescence process are the mechanisms causingthe phase transformations in effloresced salts as well as the mechanisms by which the salts are brought to the surface through capillary rise. A key factor in both appears to be the $\mathrm{Na}_{2} \mathrm{CO}_{3}$ and $\mathrm{Na}_{2} \mathrm{SO}_{4}$ chemistry. The solubility of the $\mathrm{Na}_{2} \mathrm{CO}_{3}$ and $\mathrm{Na}_{2} \mathrm{SO}_{4}$ salt-water system were studied at 0 to $100{ }^{\circ} \mathrm{C}$ by isothermal method, and the corresponding equilibrium diagram was plotted(Fig. 8). The phase equilibrium of salt-water system was affected by temperature. The Fig. 8a shows sodium bicarbonate, trona and sodium carbonate monocarbonate at low temperature (reprinted from Klauber et al., 2013). The main solid phase component in liquid in the range of 20-40 ${ }^{\circ} \mathrm{C}$ was $\mathrm{NaHCO}_{3}$. Water loss from the residue, especially at the surface, drives the transformation of $\mathrm{NaHCO}_{3}$ into sodium carbonate monohydrate being consistent with results discussed in section 3.1.

The diagram shows the phase diagram of $\mathrm{Na}_{2} \mathrm{SO}_{4}$-water binary system at low temperature (Fig. 8b) (redrawn from Niu et al., 2002). In column C2, due to the addition of phosphogypsum, Eqs.6 above shows that the generated sulfate ions react with a large number of free sodium ions in bauxite residue to produce sodium sulfate. In a binary water and salt system, $\mathrm{Na}_{2} \mathrm{SO}_{4}$ will form a stable hydrated salt of $\mathrm{Na}_{2} \mathrm{SO}_{4} \cdot 10 \mathrm{H}_{2} \mathrm{O}$ with water at low temperature. The $\mathrm{Na}_{2} \mathrm{SO}_{4} \cdot 10 \mathrm{H}_{2} \mathrm{O}$ is then converted into $\mathrm{Na}_{2} \mathrm{SO}_{4}$ at $32.38^{\circ} \mathrm{C}$, through dehydration. Therefore, amorphous $\mathrm{Na}_{2} \mathrm{SO}_{4}$ will be transformed into $\mathrm{Na}_{2} \mathrm{SO}_{4} \cdot 10 \mathrm{H}_{2} \mathrm{O}$ having a crystal structure through phase transformation. Its characteristic peak was observed with XRD determination (detailed in section 3.4).To conclude, the phase equilibrium diagram of $\mathrm{Na}_{2} \mathrm{CO}_{3}$ and $\mathrm{Na}_{2} \mathrm{SO}_{4}$ showed variation in composition of the effloresced material. In $\mathrm{C} 1$ it is 
mainly sodium carbonate, which is strongly alkaline, while in C2 it is mainly sodium sulfate (neutral salt) mixed with a small amount of sodium carbonate and sodium bicarbonate. Therefore, carbonate and bicarbonate in C2 is slightly less than that in $\mathrm{C} 1$, and its $\mathrm{pH}$ value is slightly lower than that of $\mathrm{C} 1$. This is also why the $\mathrm{pH}$ value of the effloresced material in $\mathrm{C} 2$ does not change much with time, and the alkaline anion concentrations of carbonate and bicarbonate do not change much in the later period of the investigation. Simultaneously, it also demonstrates that addition of phosphogypsum changes the composition of alkaline effloresced materials, and converts some of them into neutral salts with higher molar mass, which alleviates alkaline dust production to the surrounding environment but promotes the amounts of efflorescence.

\subsection{XANES spectrum analysis}

The Na K-edge X-ray absorption near edge structure (XANES) spectra (Fig.9a) collected from the surface $(0 \mathrm{~cm})$ and $45 \mathrm{~cm}$ deep have been normalized. The XANES spectra have two obvious feature absorption peaks a and b.C1 surface feature absorption peak a (location: 1067.0 \pm 0.2ev, normalized intensity: 0.073) and feature absorption peak b (location: 1071.0 $\pm 0.2 \mathrm{ev}$, normalized intensity: 0.072 ); $45 \mathrm{~cm}$ feature absorption peak a (position: $1067.0 \pm 0.2 \mathrm{ev}$, normalized intensity: 0.060) and feature absorption peak b (position: $1071.0 \pm 0.2 \mathrm{ev}$, normalized intensity: 0.058); C2 surface feature absorption peak a (position: 1068 \pm 0.2ev, normalized strength: 0.098) and feature absorption peak b (position: $1071.0 \pm 0.2 \mathrm{ev}$, normalized strength: 0.100 ); $45 \mathrm{~cm}$ feature absorption peak a (position: $1068.0 \pm 0.2 \mathrm{ev}$, normalized intensity: 0.084 ) and feature absorption peak $\mathrm{b}$ (position: $1071.0 \pm 0.2 \mathrm{ev}$, normalized intensity: 0.085). The XANES spectra for reference materials were obtained from cancrinite (adsorption peaks of $\mathrm{b}$ and e, located at 1067.5 and $1072.0 \mathrm{eV}$, normalized intensities of 0.068 and 0.072). XANES analysis of Na K-edge indicated that two prominent absorption peaks $\mathrm{b}$ and e, from $\mathrm{C} 2-0$ and $\mathrm{C} 2-45$ residues, were almost uniform and similar to the cancrinite spectrum except for the $\mathrm{C} 1-0$ and $\mathrm{C} 1-45$ residues. The local ordering 
around $\mathrm{Na}(\mathrm{Na}$ is in a tetrahedral position surrounded by one $\mathrm{CO} 3$ at $2.701 \AA$ and three $\mathrm{O}$ at $2.398 \AA$ in a trigonal pyramid) did not change (Neuville et al., 2004). This indicated that phosphogypsum had no effect on the phase transformation of cancrinite in bauxite residue.

The sodium STXM imaging of 0 and $45 \mathrm{~cm}$ depth in $\mathrm{C} 1$ and $\mathrm{C} 2$ are presented in Fig. 9b. The X-ray absorption images of 0 and $45 \mathrm{~cm}$ depth bauxite residue in $\mathrm{C} 1$ at the spatial resolution of 30-50 $\mathrm{nm}$ (spatial distribution of mesoporous scale) are shown in Fig. 9 (C1-0 and C1-45). The spatial distribution of $\mathrm{Na}$ in the surface layer is relatively dense (the darker the color, the more Na content) (Kong et al., 2017b). The distribution is sparse at a depth of $45 \mathrm{~cm}$, the spatial distribution of $\mathrm{Na}$ in the surface layer is relatively concentrated, and $\mathrm{Na}$ at $45 \mathrm{~cm}$ is uniformly dispersed. The X-ray absorption images of 0 and $45 \mathrm{~cm}$ depth in $\mathrm{C} 2$, at spatial resolution of $30-50 \mathrm{~nm}$ (spatial distribution of mesoporous scale), are presented in Fig. 9 (C2-0 and C2-45). Sodium was densely distributed in space at the surface layer and sparsely distributed at depth $(45 \mathrm{~cm})$. Both $\mathrm{C} 1$ and $\mathrm{C} 2$ showed that $\mathrm{Na}$ was densely distributed in the surface layer, and $\mathrm{Na}$ distribution was sparser with an increase in depth. The mesoporous scale spatial distribution of $\mathrm{Na}$ in bauxite residue $(\mathrm{C} 2)$ at the surface and $45 \mathrm{~cm}$ depth, was denser than that of the original bauxite residue (C1). The mesoporous scale spatial distribution of $\mathrm{Na}$ in bauxite residue was changed by phosphogypsum, and the effect on the bauxite residue surface was more apparent. Using NEXAFS analysis, Kong et al. (2017b) found that acid treatment and gypsum combination had no effect on $\mathrm{Na}$ speciation but affected its distribution. The spatial distribution of $\mathrm{Na}$ further indicated that phosphogypsum treatment lead to dissolve more alkaline minerals and changed the chemical form of $\mathrm{Na}$ minerals in the residue.

\section{Conclusions}

This work has revealed that effloresced materials on the surface of bauxite residue are formed through the migration of soluble alkaline ions along with water. During the 
first 150 days, $\mathrm{CO}_{3}{ }^{2-}$ and $\mathrm{HCO}_{3}{ }^{-}$respectively increased from 141.3 and $31.28 \mathrm{mmol} / \mathrm{L}$ to 256.7 and $46.84 \mathrm{mmol} / \mathrm{L}$, and $\mathrm{Na}^{+}$and $\mathrm{Ca}^{2+}$ increased from 76.34 and $3.12 \mathrm{mmol} / \mathrm{L}$ to 216.9 and $8.36 \mathrm{mmol} / \mathrm{L}$, respectively. Sodium salts are the main soluble substances formed. During the leaching process, $\mathrm{pH}$ and free alkali decreased in surface residue $(0-15 \mathrm{~cm})$. The efflorescence phenomenon began to appear gradually during 90-150 days and $\mathrm{pH}$ and free alkali content in $\mathrm{C} 2$ increased from 8.68 and $8.44 \mathrm{mmol} / \mathrm{L}$ at the surface, to 9.21 and $8.56 \mathrm{mmol} / \mathrm{L}$ at $55 \mathrm{~cm}$ depth, respectively. The key factors for dust formation at conventional BRDAs are particle size, capillary porosity and moisture content during the efflorescence process. The solid phase transformation of sodium carbonate and sodium sulfate in $\mathrm{C} 1$ and $\mathrm{C} 2$ explains the conversion of efflorescence materials in bauxite residue (sodium carbonate - sodium bicarbonate; sodium sulfate - sodium sulfate crystal water). XANES spectra revealed the spatial distribution of $\mathrm{Na}$ on the surface of $\mathrm{C} 1$ and $\mathrm{C} 2$ which was relatively concentrated, whilst $\mathrm{Na}$ was uniformly dispersed at $45 \mathrm{~cm}$, and $\mathrm{Na}$ distribution became sparser with an increase in depth. Phosphogypsum reduces the occurrence of alkaline efflorescence efficiently. More significantly, these finding are beneficial in order to eliminate environmental risk of alkaline dust pollution and have an important implication for the phosphogypsum used as a common amendment application in rehabilitation on BRDAs in the future.

\section{Declaration of Competing Interest}

The authors declare that they have no known competing financial interests or personal relationships that could have appeared to influence the work reported in this paper.

\section{Acknowledgments}

This work was supported by the National Key Research and Development Program of China (No. 2019YFC1803605); and the National Natural Science Foundation of China (No. 41877511).

\section{References}


Bray, A.W., Stewart, D.I., Courtney, R., Rout, S.P., Humphreys, P.N., Mayes, W.M., Burke, I.T., 2018. Sustained Bauxite Residue Rehabilitation with Gypsum and Organic Matter 16 years after Initial Treatment. Environ. Sci. Technol. 52, 152-161.

Burke, I.T., Peacock, C.L., Lockwood, C.L., Stewart, D.I., Mortimer, R.J.G., Ward, M.B., Renforth, P., Gruiz, K., Mayes, W.M., 2013. Behavior of Aluminum, Arsenic, and Vanadium during the Neutralization of Red Mud Leachate by $\mathrm{HCl}$, Gypsum, or Seawater. Environ. Sci. Technol. 47, 6527-6535.

Collins, R.N., Clark, M.W., Payne, T.E., 2014. Solid phases responsible for $\mathrm{Mn}^{\mathrm{II}}, \mathrm{Cr}^{\mathrm{III},} \mathrm{Co}^{\mathrm{II}}, \mathrm{Ni}$, $\mathrm{Cu}^{\mathrm{II}}$ and $\mathrm{Zn}$ immobilization by a modified bauxite refinery residue (red mud) at $\mathrm{pH}$ 7.5. Chem. Eng. J. 236, 419-429.

Courtney, R., Timpson, J.P., 2004. Nutrient status of vegetation grown in alkaline bauxite processing residue amended with gypsum and thermally dried sewage sludge - A two year field study. Plant Soil. 266, 187-194.

Courtney, R., Harrington, T., 2012. Growth and nutrition of Holcuslanatus in bauxite residue amended with combinations of spent mushroom compost and gypsum. Land Degrad. Dev. 23, 144-149.

Courtney, R., Feeney, E., O’Grady, A., 2014. An ecological assessment of rehabilitated bauxite residue. Ecol. Eng. 73, 373-379.

Courtney, R., Xue, S.G., 2019. Rehabilitation of bauxite residue to support soil development and grassland establishment. J. Cent. South Univ. 26, 353-360.

Ding, X.H., Xu, G., Liu, W.V., Yang, L., Albijanic, B., 2019. Effect of polymer stabilizers' viscosity on red sand structure strength and dust pollution resistance. Powder Technol. 352, $117-125$.

Gelencser, A., Kovats, N., Turoczi, B., Rostasi, A., Hoffer, A., Imre, K., Nyiro-Kosa, I., Csakberenyi-Malasics, D., Toth, A., Czitrovszky, A., Nagy, A., Nagy, S., Acs, A., Kovacs, A., Ferincz, A., Hartyani, Z., Posfai, M., 2011. The Red Mud Accident in Ajka (Hungary): Characterization and Potential Health Effects of Fugitive Dust. Environ. Sci. Technol. 45, 1608-1615.

Gomes, H.I., Mayes, W.M., Rogerson, M., Stewart, D.I., Burke, I.T., 2016. Alkaline residues and the environment: a review of impacts, management practices and opportunities. J. Clean. Prod. 
Grafe, M., Power, G., Klauber, C., 2011. Bauxite residue issues: III. Alkalinity and associated chemistry. Hydrometallurgy. 108, 60-79.

Higgins, D., Curtin, T., Burke, I., Courtney, R., 2018. The potential for constructed wetland mechanisms to treat alkaline bauxite residue leachate: carbonation and precipitate characterization. Environ. Sci. Pollut. R. 25, 29451-29458.

Hong, S.Y., Glasser, F.P., 2002. Alkali sorption by C-S-H and C-A-S-H gels: Part II. Role of alumina. Cement. Concrete Res. 32, 1101-1111.

Huang, J., Lin, L., Yu, Y.J., Lan, M.Z., Zhang, J.S., Gao, D.F., Wang, X.T., Yang, J.B., 2014. Technical and Product Evaluation of Industrial Solid Waste. China Standard Press, Beijing, 2014. Huang, Y.F., Chai, W.C., Han, G.H., Wang, W.J., Yang, S.Z., Liu, J.T., 2016. A perspective of stepwise utilisation of Bayer red mud: Step two-Extracting and recovering Ti from Ti-enriched tailing with acid leaching and precipitate flotation. J. Hazard. Mater. 307, 318-327. Indraratna, B., Athukorala, R., Vinod, J., 2013. Estimating the rate of erosion of a silty sand treated with lignosulfonate. J. Geotech. Geoenviron. 139, 701-714. Johnston, M., Clark, M.W., Mcmahon, P., Ward, N., 2010. Alkalinity conversion of bauxite refinery residues by neutralization. J. Hazard. Mater. 182, 710-715. Jones, B.E.H., Haynes, R.J., Phillips, I.R., 2011. Influence of organic waste and residue mud additions on chemical, physical and microbial properties of bauxite residue sand. Environ. Sci. Pollut. R. 18, 199-211.

Khaitan, S., Dzombak, D.A., Lowry, G.V., 2009. Chemistry of the acid neutralization capacity of bauxite residue. Environ. Eng. Sci. 26, 873-881. evolution of alkaline characteristics in bauxite residue. J. Clean. Prod. 143, 224-230. Kong, X.F., Li, M., Xue, S.G., Hartley, W., Chen, C.R., Wu, C., Li, X.F., Li, Y.W., 2017b. Acid transformation of bauxite residue: conversion of its alkaline characteristics. J. Hazard. Mater. 324, 382-390. 
Lehoux, A.P., Lockwood, C.L., Mayes, W.M., Stewart, D.I., Mortimer, R.J., Gruiz, K., Burke, I.T., 2013. Gypsum addition to soils contaminated by red mud: implications for aluminium, arsenic, molybdenum and vanadium solubility. Environ. Geochem. Hlth. 35, 643-656.

Li, X.F., Ye, Y.Z., Xue, S.G., Wu, C., Kong, X.F., Hartley, W., Li, Y.W., 2018. Leaching optimization and dissolution behavior of alkaline anion in bauxite residue. T. Nonferr. Metal. Soc. $06,1248-1255$.

Li, X.F., Guo, Y., Zhu, F., Huang, L.B., Hartley, W., Li, Y.W., Kong, X.F., Xue, S.G., 2019. Alkalinity stabilization behavior of bauxite residue: Ca-driving regulation characteristics of gypsum. J. Cent. South Univ. 26, 383-392.

Liu, W.C., Yang, J.K., Xiao, B., 2009. Application of Bayer red mud for iron recovery and building material production from alumosilicate residues. J. Hazard. Mater. 161, 474-478.

Luo, M.X., Qi, X.J., Zhang, Y.R., Ren, Y.F., Tong, J.C., Chen, Z.N., Hou, Y.M., Yeerkebai, N., Wang, H.T., Feng, S.J., Li, F.T., 2017. Study on dealkalization and settling performance of red mud. Environ. Sci. Pollut. R. 24, 1-9.

Menzies, N., Fulton, I.M., Morrell, W.J., 2004. Seawater Neutralization of Alkaline Bauxite Residue and Implications for Revegetation. J. Environ. Qual. 33, 1877-1884.

Mishra, B., Staley, A., Kirkpatrick, D., 2002. Recovery of value-added products from red mud. Min. Metall. Explor. 19, 87-94.

Neuville, D.R., Cormier, L., Flank, M.A., Prado, R.J., Lagarde, P., 2004. Na K-edge XANES spectra of minerals and glasses. Eur. J. Mineral. 16, 809-816.

Niu, Z.D., Cheng, F.Q., 2002. Phase diagram of water and salt system and its application. Tianjin university press, Tianjin. (in Chinese)

Paradis, M., Duchesne, J., Lamontagne, A., Isabel, D., 2007. Long-term neutralisation potential of red mud bauxite with brine amendment for the neutralisation of acidic mine tailings. Appl. Geochem. 22, 2326-2333.

Rollings, R.S., Burkes, J.P., Rollings, M.P., 1999. Sulfate attack on cement-stabilized sand. J. Geotech. Geoenviron. 125, 364-372.

Suryavanshi, A.K., Scantlebury, J.D., Lyon, S.B., 1996. Mechanism of Friedel's salt formation in cements rich in tri-calcium aluminate. Cement. Concrete Res. 26, 717-727.

Santini, T.C., Hinz, C., Rate, A.W., Gilkes. R.J., Carter, C.M., 2011. In situ neutralization of 
uncarbonated bauxite residue mud by cross layer leaching with carbonated bauxite residue mud. J. Hazard. Mater. 194, 119-127.

Santini, T.C., Fey, M.V., 2012. Synthesis of hydrotalcite by neutralization of bauxite residue mud leachate with acidic saline drainage water. Appl. Clay Sci. 55, 94-99.

Santini, T.C., Kerr, J.L., Warren, L.A., 2015. Microbially-driven strategies for bioremediation of bauxite residue. J. Hazard. Mater. 293, 131-157.

Santini, T.C., Peng, Y.G., 2017. Microbial fermentation of organic carbon substrates drives rapid pH neutralisation and element removal in alkaline bauxite residue leachate. Environ. Sci. Technol. $51,12592-12601$.

Sharma, J.V., Lhouvum, G., Chauhan, S., Lal, B., Singh, T.P., Paul, V., 2004. Rehabilitation of red mud ponds at INDAL, Belgaum (Karnataka). Indian Forester. 130, 481-497.

Shi, B., Qu, Y., Li, H., 2017. Gypsum alleviated hydroxyl radical-mediated oxidative damages caused by alkaline bauxite residue in leaves of Atriplexcanescens. Ecol. Eng. 98, 166-171.

Smiciklas, I., Smiljanic, S., Peric-Grujic, A., Sljivic-Ivanovic, M., Mitric, M., Antonovic, D., 2014. Effect of acid treatment on red mud properties with implicationson Ni (II) sorption and stability. Chem. Eng. J. 242, 27-35.

Sofra, F., Boger, D.V., 2002. Environmental rheology for waste minimisation in the minerals industry. Chem. Eng. J. 86, 319-330.

Thornber, M., Binet, D., 1999. Caustic Soda Adsorption on Bayer Residues. In 5th International Alumina Quality Workshop; AQW Inc. Bunbury, 498-507.

Vinod, J.S., Indraratna, B., Mahamud, M., 2010. Stabilisation of an erodible soil using a chemical admixture. P. ICE.-Ground Improvement. 163, 43-51.

Wang, Y.X., Zhang, T.A., Lyu, G.Z., Guo, F.F., Zhang, W.G., Zhang, Y.H., 2018. Recovery of alkali and alumina from bauxite residue (red mud) andcomplete reuse of the treated residue. J. Clean. Prod. 188, 456-465.

Wen, Z., Ma, S., Zheng, S., Zhang, Y., Liang, Y., 2016. Assessment of environmental risk for red mud storage facility in China: a case study in Shandong Province. Environ. Sci. Pollut. R. 23, 11193-11208.

Wieslawa, N.W., 1999. Effect of $\mathrm{Na}$ and $\mathrm{Al}$ on the phase composition and morphology of autoclaved calcium silicate hydrates. Cement. Concrete Res. 29, 1759-1767. 
Xu, G., Ding, X.H., Kuruppu, M., Zhou, W., Biswas, W., 2018. Research and application of non-traditional chemical stabilizers on bauxite residue (red sand) dust control, a review. Sci. Total. Environ. 616-617, 1552-1565.

Xue, S.G., Zhu, F., Kong, X.F., Wu, C., Huang, L., Huang, N., Hartley, W., 2016. A review of the characterization and revegetation of bauxite residues (Red mud). Environ. Sci. Pollut. R. 23, $1120-1132$.

Xue, S.G., Li, M., Jiang, J., Millar, G.J., Li, C.X., Kong, X.F., 2019b. Phosphogypsum stabilization of bauxite residue: Conversion of its alkaline characteristics. J. Environ. Sci.-China. $77,1-10$.

Xue, S.G., Wu, Y.J., Li, Y.W., Kong, X.F., Zhu, F., William, H., Li, X.F., Ye, Y.Z., 2019a. Industrial wastes applications for alkalinity regulation in bauxite residue: A comprehensive review. J. Cent. South Univ. 26, 268-288.

Xue, S.G., Ke, W.S., Zhu, F., Ye, Y.Z., Liu, Z., Fan, J.R., Hartley, W., 2020. Effect of phosphogypsum and poultry manure on aggregate-associatedalkaline characteristics in bauxite residue. J. Environ. Manage. 256, 109981.

Yoon, K., Cho, D.W., Tsang, Y.F., Tsang, D.C.W., Kwon, E.E., Song, H., 2019. Synthesis of functionalised biochar using red mud, lignin, and carbondioxide as raw materials. Chem. Eng. J. $361,1597-1604$.

Zhu, F., Xue, S.G., Hartley, W., Huang, L., Wu, C., Li, X.F., 2016. Novel predictors of soil genesis following natural weathering processes of bauxite residues. Environ. Sci. Pollut. R. 23, 2856-2863.

Zhu, F., Hou, J.T., Xue, S.G., Wu, C., Wang, Q.L., Hartley, W., 2017. Vermicompost and gypsum amendments improve aggregate formation in bauxite residue. Land Degrad. Dev. 28, 2109-2120. 